
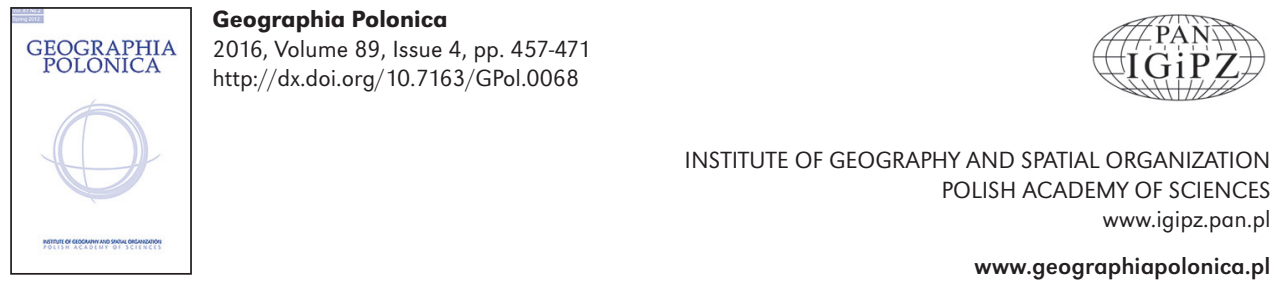

\title{
ECONOMIC RESILIENCE: THE CASE OF POLAND AND CERTAIN EUROPEAN REGIONS
}

\author{
Grzegorz Masik \\ Institute of Geography \\ University of Gdańsk \\ Bażyńskiego 4, 80-952 Gdańsk: Poland \\ e-mail: geogm@ug.edu.pl
}

\begin{abstract}
The study of economic resilience represents a relatively new subject of debate within the framework of regional studies. Here, the author first presents the evolutionary approach to resilience, and within it the agency perspective; before refocusing on the macroeconomic policy pursued in Poland, which is deemed to have spared the country and many of its regions from the recession otherwise experienced so widely during the crisis in Europe. The author then turns to a characterisation of eight European regions, including one in Poland, describing the actions taken and strategies pursued with a view to counteracting the negative effects of the crisis, and building economic resilience to future events of the same kind.
\end{abstract}

\section{Key words}

economic resilience $\bullet$ evolutionary approach $\bullet$ agency perspective $\bullet$ economic crisis $\bullet$ Poland $\bullet$ European regions $\cdot$ Pomorskie region

\section{Concepts of economic resilience}

One concept of regional economic resilience is based on the engineering concept which focuses on the resistance of a system to shocks and the speed of its return or 'bounce-back' to a pre-shock state or equilibrium. The faster a system returns to equilibrium, the more resilient it is (Holling 1996). Environmental studies assume that resilience refers to a biological capacity to adapt to and thrive under adverse environmental conditions (Christopherson et al. 2010). This concept has been transferred to the social sciences and public policy to identify responsive capacities on the part of places and social systems, to global threats such as economic crisis and climate change (MacKinnon \& Derickson 2013). Where economics is concerned, resilience has been defined in terms of return to a fixed and narrowlydefined equilibrium (as measured by reference to employment, for example) or, in the more liberal version, multiple equilibria (Christopherson et al. 2010). Another - adaptive - concept 
of resilience sees this as a dynamic attribute associated with a process of continual development (Pendall et al. 2010). The essence of adaptive resilience is an ability to change as circumstances change, to adapt and, where appropriate, transform (Goldstein et al. 2015).

Regional resilience can therefore be defined as an "ability of a region to anticipate, prepare for, respond to, and recover from a disturbance" (Foster 2007: 14). According to Briguglio et al. (2009: 233), economic resilience refers to the "policy-induced ability of an economy to recover from or adjust to the negative impacts of adverse exogenous shocks and to benefit from positive shocks". Santos and Partidário (2011: 1519) assert that resilience can be described as "the capacity of a system (e.g. a region, an economic activity, a city, a household) to absorb disturbance and reorganise without collapsing or considerably changing their identity". It implies that exogenous shocks can contribute to future positive changes that in some events are less possible in a period of economic growth.

One attempt at conceptualising resilience is an evolutionary approach. It sees economic resilience in terms of complex socio-ecological systems (Simmie \& Martin 2010; Davoudi 2013). The evolutionary approach draws attention to the cultural, institutional and social contingencies of regions that determine their ability to adapt to changing market conditions, and the emergence of new technologies and competitors, and thus their capacity to create new development trajectories (Boschma \& Martin 2007; Bristow 2010). This approach "recognises the importance of political and social processes without eliminating the economic from consideration and in a way that is acutely sensitive to context, specifically including that defined by geographic difference" (Hayter 2004: 96). This respect for difference is based on an embeddedness of economies in which economic processes are socialised and politicised.

The evolutionary approach has an analogy with natural ecosystems, as it assumes that resilient regions have certain key features. They require diversity (as opposed to uniformity) in the number of 'species' of business, institutions and sources of energy. Resilience suggests a need to reinforce local food production and the diversity of businesses owned by local people. Resilient places require modularity, or the capacity to re-organise in the event of a shock so that they can supply their core needs without reliance on transport. In other words, places need to be engaged with the wider world, but in line with an ethic of networking and information sharing, rather than mutual dependence (Hopkins 2008). Resilient places are characterised by small-scale, localised activities that are embedded in the local environment, and adapted to its limits. Cities and regions can be rendered vulnerable by over-dependence on key industrial sectors in structural decline such as coal mining, steel and shipbuilding. Thus, as well as diversity across a range of sectors, resilience also implies that these sectors should be relatively small-scale, such that no one sector or company becomes dominant locally, and there is always some spare capacity for adaptation in the event of structural change and industrial decline. This also implies that resilience is characterised by dispersion rather than centralised control over systems (Bristow \& Wells 2005; Gibbs et al. 2005; Bristow 2010). Resilience requires mutual use of local assets, capacities and resources and localised production, trading and exchange. The evolutionary approach to resilience also implies a healthy core or supporting economy of family, neighbourhood, community and civil society, which is strong in reciprocity, co-operation, sharing and collaboration in the delivery of essential services, care provision and care for families (Hopkins 2008; Jackson 2009).

The agency perspective in resilience is a quite new approach in theories surrounding complex adaptive systems. This perspective assumes that an active role in shaping regional resilience played by local and regional policymakers, institutions, NGO's and other stakeholders. Folke (2006) asserts that policymakers do not control all the factors shaping resilience, but can help manage and support the development of appropriate capacities 
for self-organisation and adaptation. Bristow and Healy (2014a) say that the networked nature of governance and policy is critical in resilience. Institutions of governance act as a connector, and they provide collective agency for more complex communication and co-operation. Human agents have capacities to imagine, anticipate and respond to change, as well as the ability to take pro-active, intentional action to build up the capacities of resilient regions. In this meaning, resilience denotes self-organisation and a people-oriented system (Bristow \& Healy 2014b). Furthermore, Davidson (2010) emphasizes that human agency may function through both individual and collective forms, and at multiple scales including those of the household, community, region and country. But only strong actors play a crucial role in shaping the social norms and rationalities for action influencing agents' behaviour in regions (Bristow \& Healy 2015).

Significant in shaping resilience by agency are strong relationships between the public, private and social economy sectors, governance institutions and the environment ( $\mathrm{Mcl}$ nroy \& Longlands 2010). Skelcher (2005) says that polycentric governance systems are deemed better equipped to foster resilience: issues of differing geographical range can be managed at different spatial scales, their high degree of overlap and redundancy making them less vulnerable if one institution or approach fails; while a large number of institutional entities promotes experimentation with new approaches, and maximises opportunities for mutual learning. A critical role is also played by subnational actors, in terms of mobilising knowledge of the economic environment. They know territorial specificities and are able to assess the particular vulnerabilities, risks and opportunities associated with their territory (Bristow \& Healy 2014a).

Interventions may concern structural adjustment mechanisms, such as automatic fiscal stabilisers or may involve purposeful actions. Activities can include policies which provide support for companies affected adversely, in the form of temporary wage subsidies or investments in rapid redeployment initiatives to support workers' adaptability to changing labour market conditions, or providing funds to support individual re-training or skills enhancement. A number of interventions can be combined to create an 'Economic Resilience Package' to "alleviate the worst effects of the recession". In some cases, economic resilience may be enhanced through prospective actions that seek to strengthen economic structures and systems, e.g. by diversifying regional output and encouraging modularity so that shocks to the system can be contained (Bristow \& Healy 2014a).

From the macroeconomic point of view, it was Briguglio et al. (2009) who developed the concept of economic resilience. These authors deem it to be determined by macroeconomic stability, fiscal deficit, inflation and unemployment and external debt, but also by microeconomic market efficiency (including efficient market mechanisms), good governance (appropriate government intervention to foster economic resilience), and a developed and responsible society possessing highlevel qualifications and enjoying good health. In contrast to resilience, the same authors define economic vulnerability as "exposure of an economy to exogenous shocks, arising out of economic openness" (p. 232). They also suggest that vulnerability is affected by economic openness, export concentration and dependence on strategic imports. However, Christopherson et al. (2010) point out that there are several, universal factors of particular importance that allow a given region to adjust and adapt to changing conditions over time. These are: a strong regional system of innovation; strengths in the factors that create a 'learning region'; modern productive infrastructure (transport, broadband provision, etc.); a skilled, innovative and entrepreneurial workforce; and a supportive financial system providing patient capital and diversified economic base not over-reliant on a single industry.

The aim of the work detailed here has been to identify how state and regional agencies have responded to economic crisis. To achieve this aim, analysis begins by outlining the 
macroeconomic actions of the Polish government taken in line with the macroeconomic characteristics in the country. The author explains why Poland proved resilient during the economic crisis in Europe. The effectiveness of measures resorted to in eight European regions are then presented in the context of the evolutionary approach and the agency perspective. The analysis relates mainly to the results of qualitative research that allow trends as regards policies in the regions to be accounted for. To this end, over 30 interviews in each of the eight selected European regions were conducted, with representatives of ministries, labour institutions, business chambers, NGOs, entrepreneurs and regional and local authorities ${ }^{1}$. The regions represent different stages of economic and social development, and are of differing adaptability, meaning that they are also characterised by different ways of exiting from the crisis. The selection of regions made takes account of anticipated diversity in terms of potential resistance to crisis, advancement of economic development, membership or non-membership of the eurozone and openness of the economy. In this context, a further aim of this work has been to show which characteristics of regions strengthen their resilience. Attention has here been paid to the structural conditions characterising regions, the importance of the metropolitan area, the importance of exports and other characteristics arising out of the earlier stages of development. Some common actions and key messages from the regions are also mentioned at the end.

\section{Macroeconomic policy in Poland}

The economic crisis in Europe and the United States has not triggered an economic recession in Poland, hence the Polish economy has proved more resilient than anyone could have expected. Many academics and practitioners are seeking reasons for this, but public debate

\footnotetext{
1 Interviews were conducted within the framework of the project entitled Economic Crisis: Resilience of Regions (ECR2), Programme ESPON 2013.
}

in Poland tends to emphasise a significant external factor affecting the stability of the economy, i.e. European funds. The inflow of funds invested mainly in infrastructure has contributed to increased turnover in the economy, which enabled growth to be maintained even during the crisis in Europe. In the new Member States and certain old ones, EU structural funds together with the required own domestic contribution do account for a significant share of total public investment. For example, in 2009-2011, they on average accounted for over $70 \%$ of expenditure in Estonia, more than $50 \%$ in Poland and less than 40\% in Greece. Whereas, based on the interviews one can say that in countries (like the UK), in which the share of public investment is negligible, these may still have a special role to play where niche investment activity is concerned (Healy \& Bristow 2013).

Another key factor contributing to Poland's economic resilience has been a stable banking system as a reflection of a conservative policy pursued by the sector, including a favourable loan-deposit ratio and relatively limited lending in foreign currencies. Also of importance to positive GDP growth was a weakening of the Polish currency as a result of the global financial crisis and the outflow of capital to developed countries. Depreciation of the currency made Polish companies more competitive as they sold goods on world markets at prices lower than before the crisis (Rachwał 2011). The Polish Zloty (PLN) has a floating exchange rate and its fluctuations are influenced by the relationships between other currencies, especially the Euro. Polish economists claim that Polish currency was strengthening at the time of the most favourable economic situation, with large inflows of foreign capital (Kębłowski \& Welfe 2010). That is why Polish exporting companies had to increase their productivity and implement certain restructuring processes. On the other hand, at the time of the financial crisis in Europe, the weakening of the Polish currency had a stimulating impact on Polish exports, and Poland experienced an overbalance in domestic trade. It can thus be assumed that the Polish 
economy was able to absorb the external economic shock. The floating rate of the zloty exchange makes it possible for the Polish economy to adjust to external macroeconomic conditions (Masik 2014).

The countercyclical fiscal policy of the Polish government undoubtedly contributed to mitigation of the negative effects of the financial crisis. During the economic boom of the years 2003-2007, the budget deficit fell from over $6 \%$ of GDP to less than $2 \%$. During the economic downturn in 2009, it increased again to above 7\% of GDP. By 2012, the budget deficit had fallen to less than 4\% of GDP. This fiscal policy allowed positive GDP growth to be maintained, but caused an increase in debt (Tab. 1).

As a result of the austerity measures of 2010 there was a slight decrease in expenditure from the state budget, and at the same time a marked decline in revenue (Fig. 1). In subsequent years, expenditure and income

Table 1. Macroeconomic indicators for Poland in the period 2002-2014

\begin{tabular}{|c|c|c|c|c|c|c|c|c|c|c|c|c|c|}
\hline Categories & 2002 & 2003 & 2004 & 2005 & 2006 & 2007 & 2008 & 2009 & 2010 & 2011 & 2012 & 2013 & 2014 \\
\hline $\begin{array}{l}\text { GDP - \% increase } \\
\text { in comparison } \\
\text { with previous year } \\
\text { Deficit/Surplus } \\
\text { of sector } \\
\text { of government } \\
\text { institutions and } \\
\text { local authorities } \\
\text { as \% of GDP } \\
\text { Debt of sector } \\
\text { of government } \\
\text { institutions and } \\
\text { local authorities } \\
\text { as \% of GDP }\end{array}$ & 1.4 & 3.9 & 5.3 & 3.6 & 6.2 & 6.8 & 5.1 & 1.6 & 3.9 & 5.0 & 1.6 & 1.3 & 3.3 \\
\hline
\end{tabular}

*For the years 2002-2014, and in accordance with ESA 2010 methodology

Source: CSO 2016.

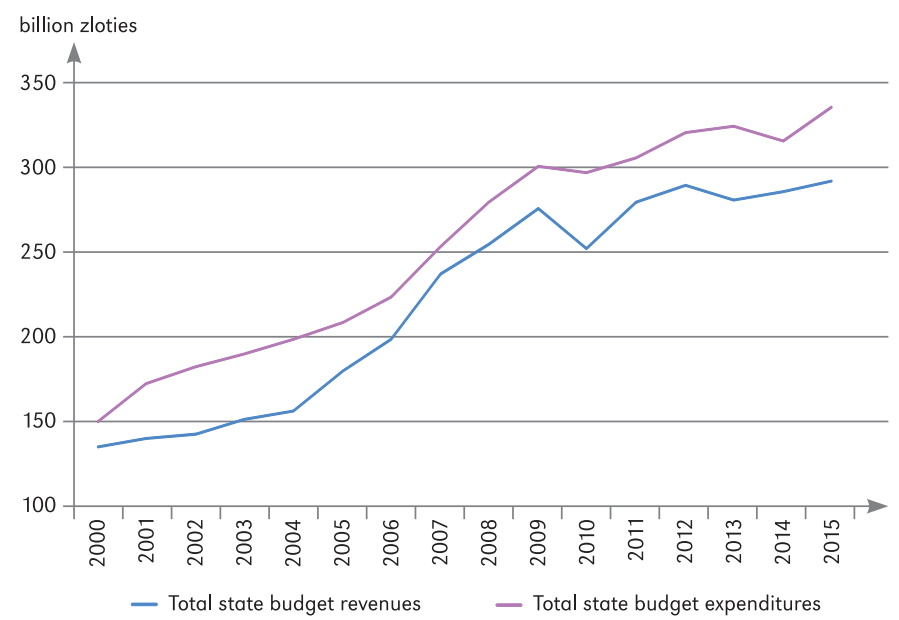

Figure 1. State budget revenues and expenditures in Poland in the years 2000-2015 Source: CSO (2016). 
began to rise, but 2013 revenues were again slightly lower, resulting in a drop in spending in 2014. At the same time, in 2014, a transfer of 150 bn zloties (ca. 35 bn Euro) from the Open Pension Funds (equity funds - OFEs) to the state Social Insurance Institution (ZUS), allowed for a reduction in subsidies to ZUS from the state budget. These actions reflected spending in previous years maintained at a relatively high level, allowing public money to stimulate the economy while recession raged in Europe. As a result of ZUS's acquisition of money from the OFEs, debt was reduced artificially in 2014, by more than 5 percentage points in relation to GDP (Tab. 1).

An important factor allowing economic growth in Poland to be sustained was relatively high consumption and a high level of exports. The approach of estimating GDP from the perspective of distribution holds that GDP represents the sum of the end-use of goods and services by resident institutional units (consumption and gross accumulation), plus the value of exports minus that of imports, of goods and services. In the case of the Polish economy the crisis in Europe triggered a major decline in exports in 2009, albeit with imports declining to an even greater extent (Fig. 2). This helped mitigate the effects of the crisis in Poland to some extent. In subsequent years, more positive growth of exports than imports continued, other than in 2014. A beneficial effect on the maintenance of a positive figure for GDP growth was also exerted by internal demand, which achieved a dynamic range of $5-10 \%$ per year before the recession in Europe, only to fall to just below 0 in 2009. In subsequent years, i.e. 2010 and 2011, a growth rate of almost $5 \%$ per year was achieved. As a result of a coming second wave of the crisis in 2012 and 2013, the dynamics for domestic demand again assumed a negative value. In these years, however, export growth exceeded import growth, ensuring that GDP continued to rise.

Among public activities allowing the economy to stabilise in the first wave of the crisis was monetary policy. In the years 2008-2009 the deposit interest rate determined by the
National Bank of Poland fell from 4.5 to $2 \%$. In 2010-2012 it increased from 2 to 3\%, but in 2013 it again dropped to $1 \%$. Economists interviewed for the ESPON project ${ }^{2}$ emphasised that a lowering of interest rates encouraged banks to increase financing of the real economy. During the second wave of the European crisis, the Polish economy was more vulnerable than during the first wave to external negative impulses. This was due to a stronger national currency that put an end to infrastructure projects financed from European funds from the budget for the years 20072013, and decreased domestic consumption (Masik \& Rzyski 2014).

There were also certain actions taken, not only by the Ministry of Finance and National Bank of Poland, but also by other Polish Ministries. The Ministry of Justice implemented procedures to deregulate occupations. For many of these, there are now no certificates or state examinations. In contrast, Poland, as a country in which access to almost 400 occupations was once controlled by the state, was characterised previously by one of the highest indicators in the EU for this kind of restriction. Increasing occupational mobility was thus a priority issue in the strategy to respond to the second wave of the global crisis. While deregulation of certain professions did not greatly help overcome external impulses of crisis, interviewees did indicate that these actions were changed in a good direction. This means that they can contribute to a strengthening of the economy's resilience as regards future crises. The government also introduced a "second chance policy" which means that a company declaring bankruptcy is not forced to dismiss its employers. There are also programmes introduced encouraging bankrupt entrepreneurs to start new companies.

In the years 2009-2011 the Ministry of Labour and Social Policy introduced the Act Mitigating the Effects of the Economic Crisis for Employees and Entrepreneurs. This was

\footnotetext{
2 For the purposes of the ESPON project (acronym ECR2) more than 30 interviews were conducted in Poland, with academics, state and regional authorities, NGOs and business representatives.
} 


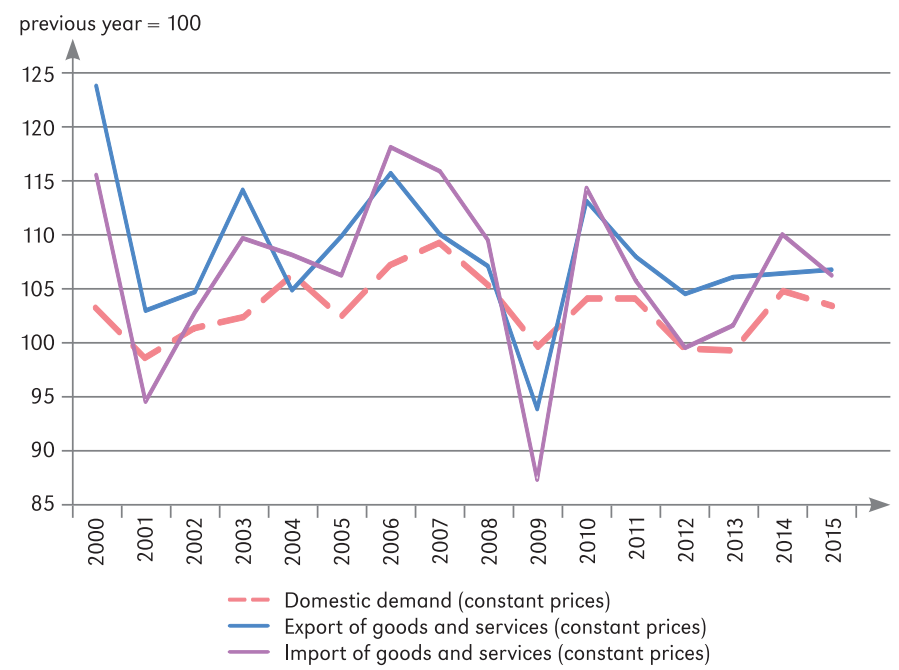

Figure 2. Domestic demand, and Poland's levels of exports and imports in the years 2000-2015 Source: based on CSO (2016).

enacted to help entrepreneurs operate and maintain jobs during times of slump. The Act allowed entrepreneurs to extend the working time settlement period to up to twelve months and to vary the time of commencement and completion of work by employees. Employees were also allowed temporarily (for up to six months) to reduce working time with a pro rata reduction of remuneration, without a requirement for the employee provided with notice of termination of employment conditions. Another measure offered under the Act was a capacity for employers (over not more than six months) to invoke so-called economic downtime, i.e. a period during which the employee does not provide work, but is on stand-by and ready to offer it when necessary. In such cases, employees are entitled to minimum remuneration, part of which is contributed by the state. However, this special tool has not been used very often in practice, as the condition of the Polish economy remained relatively good.

Another response to economic crisis was the establishing of the National Reform Programme, as a part of the Europe 2020 Strategy. The programme focuses on the concepts of sustainable growth, innovation and social inclusion. The issues of innovation and economic effectiveness are the most important here. The rationalisation tools of the financial incentives system have been introduced into the R\&D sector. Another initiative entails an increasing in the level of cluster cooperation. As part of the first and second deregulation acts, the so-called Entrepreneurship Package has also been established. Thanks to this, entrepreneurs have been able to suspend their business activity when orders were lacking. The number of audits of companies has been lowered, as have numbers of required concessions and licenses. The required total amount of registered capital of limited companies has also been lowered. In many cases entrepreneurs are permitted to submit statements instead of documents made out by officials.

Polish government also took certain actions with a view to large projects being implemented on the basis of the capital of the large state-owned companies. This capital has been invested in the so-called strategic business investments (the power industry and technical infrastructure), in order to trigger some smaller investments and projects accelerating economic development. While Polskie Inwestycje Rozwojowe (Polish Development Investments) have been established, some economists say it should have appeared earlier. Indeed, many government responses 
to the crisis proved to be rather delayed, and thus assumed many features of reactionary policy. While such operations did not manage to overcome the negative pulses during the recent crisis, the possibility for them to contribute to a future strengthening of the economy's resilience to future crises needs to be stressed.

\section{European regions' responses to the economic crisis}

The economic crisis evoked many different responses in European regions. Some actions were common, but some were tailored to regional specifics. There are key features of regional resilience and actions in analysed regions within the framework of ESPON project (Bristow et al. 2014). For example, the response in the Baden-Württemberg region in Germany benefited from the extension of an existing federal instrument of short-term work allowances i.e. more prolonged eligibility, a reduction in firms' residual costs and also firms' use of flexible working-time arrangements and short-term work to help retain their workforce (in contrast to the 1992/1993 crisis). These instruments were similar to ones used in Poland. In the short-term, pragmatic and flexible tools on the private level combined with public subsidies aimed at workforce retention in firms, helped overcome the crisis, without negative employment effects. This dialogue-oriented approach emerged as very significant in stabilising regional labour markets. Mid-term structural adjustment processes related to the restructuring of supply chains, the raising of formal qualifications in the workforce and an increased service intensity of industrial products. These measures enhanced the adaptability at a time of economic hardship and helped accelerate the recovery. However, the mid-term strategies initiated in the 1990s prepared capabilities as regards adjustment to the recovery, as these focused on structural adjustments towards internationalisation, modularity, innovation, qualification and diversification. The regional and Stuttgart authorities also responded to the economic crisis by investing in innovation infrastructures and offering "innovation vouchers" to SMEs as support for their development processes. At the federal level, investments in public research infrastructure were also increased, and a new programme for SMEs to support R\&D activities was established. Actions forming a part of the transition towards a new green energy system in the Baden-Württemberg region can be understood as a long-term response to future crises.

Estonia introduced radical austerity measures i.e. a reduction in public-sector investments and wages, and a reduction in public sector employment. At the same time value added tax was increased, along with excise taxes. As the taxation decisions were implemented quickly, there was a significant positive impact on tax revenues. The national policy response also focused on accelerated allocation of funding from the EU Structural Funds; resources initially scheduled for 2010-2011 were used in 2009. In the region of North Estonia (with Tallinn), analysed under the ESPON project, it is possible to identify factors considered supportive of resilience: a flexible labour market with a low minimum wage, flexible pay schemes (e.g. based on individual job performance), changes in legislation that simplify the dismissal of employees, a limited reach of collective agreements, and weak trade unions. It is interesting that most of the interviewees in North Estonia represented a neo-liberal approach. Highly-skilled labour alongside toleration of wage and working-hour cuts were also emphasised as ways to overcome the economic shock. North Estonia has emerged from the crisis in a better state than other parts of the country. The crisis triggered discussions on business models and productivity enhancing adjustments, and also provided motivation for learning and the consideration of their international competitiveness.

Pomorskie was one of eight regions in Poland that did not experience an employment decrease, and one of ten Polish regions that did not face a GDP decline. Relative to the whole of Poland, Pomorskie has followed the national performance and has fared well when 
compared with other Polish regions. In Pomorskie, GDP growth in 2007-2010 reached a cumulative value of $10 \%$ (with an increase of more than $12 \%$ in Poland), with significantly increased disposable income of households (by $9.5 \%$, in Poland $8.1 \%$ ). For example, in the years 2007-2012 in Pomorskie region employment rate increased by $11.8 \%$ (in Poland $2.3 \%$ ) and the number of business entities by $12.2 \%$ (in Poland 7.3\%) (Masik \& Rzyski 2014). The high level of international economic openness of the region, including a markedly high export rate, has contributed to its good performance. Pomorskie is one of the most important exporting regions in Poland (Szejgiec \& Komornicki 2015). Furthermore, its high level of diversity of exports is beneficial, as the region exports goods to the developed and economically stable countries of Western and Northern Europe, i.e. Germany, Sweden, Denmark, The Netherlands and Norway (Marshal's Office of Pomorskie Voivodeship 2008; Komornicki et al. 2015). The share of net revenues arising from the sale of innovative products for export was also higher than the national average and, for example, the years 2007-2012 brought an increase of $20.4 \%$, cf. a decrease in the country as a whole of almost $29 \%$. The index of resilience based on the above mentioned indicators has placed Pomorskie region as the most resilient in the country. This was followed by Mazowieckie (with Warsaw), Małopolskie (Kraków), Wielkopolskie (Poznań) and Dolnośląskie (Wrocław) (Masik \& Rzyski 2014). Of significance in maintaining the economic resilience of Pomorskie region were EU funds. These are considered to have allowed for a purchasing of modern technologies that triggered increased efficiency of production and preservation of low labour costs at the same time. Productivity in Poland grew faster than labour costs, and this may reflect a midterm strategy that strengthened the resilience of the region and country. A diversified economic structure of Pomorskie is considered to have a positive effect on resilience, and during the development of the region's economy no one industry was dominant. Well-qualified employees, the entrepreneurial spirit and occupational mobility of people living in Pomorskie could all be considered of great importance. The level of entrepreneurship in the region during the crisis was relatively high. This is connected with EU funding paid out to people who start their own companies, and with the self-development policy implemented in Poland. Analysis of the entrepreneurship index shows that the region is the second best in Poland. In Pomorskie region many new companies are registered every year, while a relatively small number close down (Statistical Office in Gdańsk 2012).

Liberalism, self-reliance, the lack of a demanding attitude and a relatively high level of social and human capital (as compared with other Polish regions) are factors considered to strengthen the competitiveness of the economy. The establishment in the 1970s of factories from various industries (e.g. maritime, petrochemical, paper, food and machinery) built diversity into the regional economy, thereby supporting resilience. The decisions and privatisation and restructuring of companies that began in the 1990s can be seen as a long-term strategy.

Today, regional strategies in Pomorskie mainly focus on increasing the region's transport accessibility, and there are aims to create a transport hub and to improve territorial cohesion in the region. Short-term and mid-term strategies assume support for companies enjoying a greater chance of long-term market persistence and supporting those which cooperate with research units and have a chance of achieving global success, e.g. companies representing creative industries (Grochowski et al. 2012).

An important response to the economic crisis entailed an increasing in access to repayable financial instruments - loans and guarantee funds offered by a public regional agency and supporting start-ups by providing advisory services as regards repayable financing, legal regulations and business strategies. Mid-term actions related to the labour-market focus on making universities more international and supporting students who implement research projects in cooperation with the 
business sector, as well as supporting vocational education in cooperation with business associations.

Puglia is one of the economically weaker regions in Italy. The most severe labourmarket effects of the crisis were felt in the traditional manufacturing areas and in the more-urbanised areas. The best results were in turn recorded in rural areas that specialised in high quality agri-food products and niche-based crafts, furniture and clothing. The areas of niche production performed better than those of heavy manufacturing industry. Small firm clusters that were able to benefit from fast growing, quality-conscious markets abroad were able to withstand the economic crisis. The region's export performance was stronger after the crisis than before. This suggests that the emphasis on branding and marketing around the "Made in Puglia" label was a good strategy. Entrepreneurs in the nichebased sectors attributed their success during the crisis to three attributes: the small sizes of firms that afforded a great deal of flexibility; the good relations enjoyed with the local area and local workforce and the uniqueness of the product, which was related to the power of the brand and short supply chains. The parts of the regional economy that are embedded locally but engaged globally are considered the most dynamic parts, and they strengthen the region's resilience. Generally speaking and comparing with the time before the crisis, regional policy has been much more pro-active in its spheres of competence, especially in deploying EU funds to support economic recovery and in its support for such new sectors as solar power.

The diverse economic base of South West Ireland has been an important foundation for the relative resilience of this area as compared with the rest of Ireland. This has been supported by foreign investment, as coupled with a tendency for firms to enter on to new markets, with a strong export orientation. Strong civic and social networks are one of the reasons South West Ireland has been able to respond positively to the economic shock. The networks are business networks, but also community-based collaborations and links between local authorities. It emerged that the relative resilience of the economy of metropolitan Cork in South West Ireland has been based on collaborative working, positive strategic planning, and a determination that diverse economic structure be maintained. This is a long-standing policy position, based on lessons learnt from the collapse of 'smokestack' industries in the 1980s. The crisis ensured that greater attention is now paid to innovation and sources of economic growth.

Wales was once a very significant coal mining region. After a period of transition and the collapse of many companies involved in mining there was a significant inflow of foreign investment. However, rising labor costs combined with insufficient qualifications and the recession in the world economy to generate an outflow of capital from the region. However, that region is diverse internally, with western Wales still feeling the effects of the aforesaid collapse in mining, while the greater part of eastern Wales has developed a services sector, and benefits from a better location relative to London. The areas of Wales in which the manufacturing sector and construction were highly developed proved to be affected severely by the crisis. Sub-regions characterised by a greater role for services and a well-developed tourist sector (like the Welsh capital Cardiff) have suffered less. The lack of economic diversity of Wales has affected the region adversely, given that the economy has proved over-dependent on manufacturing, external business investment and the public sector. The austerity measures introduced UKwide have had a significant impact in Wales, resulting in reductions in capital and revenue spending. The Welsh Government's response to the crisis was limited, and focused on helping to keep people in work by means of labour subsidies for businesses. These were intended to involve a breadth of stakeholders ranging from local authorities and businesses to social partners and community representatives in the development of crisis responses. While employment fell, there was clear evidence that this had been tempered to a significant 
degree by strategies deployed by businesses, households and policymakers. Instead of redundancy, there was an increase in part-time working, and acceptance of reduced-, or zerohours contracts, as well as lower rates of pay. Strong social ties exist between communities and local traders, who are seen as playing vital role in providing a service and contributing to local economic vitality. Workers in Wales appear to have been much more inclined to take pay cuts and accept reduced working hours during the crisis, than to become unemployed (Bristow \& Healy 2015). Austerity measures and immediate employment concerns have tended to result in short-term, reactive responses focused upon coping with the crisis and recovering employment, rather than encouraging longer-term transformative adaptation and change.

The situation in Western Macedonia in Greece was significantly affected by the depth of the crisis in that country as a whole. Too low a cost of money following the introduction of the euro, borrowing on the part of households to sustain consumption, a chronic foreign trade deficit, low competitiveness of the economy and the sheer number of employee benefits in the public sector all contributed to increased debt, and - in a time of crisis - to a significant increase in the cost of its operation. These factors contributed to an increase in the budget deficit of the country during the recession, and triggered a crisis. Regions especially affected were those that have not specialised in niche production, as well as those lacking export-oriented sectors (Petrakos \& Psycharis 2015). Western Macedonia does have a strategic role within Greece when it comes to energy production and energy network infrastructure. Massive installations of the Public Power Corporation were established in the area, triggering an enlargement of the public sector, and allowing the said Corporation to become the main employer. The most important effects of the crisis were high unemployment, cut-offs in salaries, cessation of trading by some firms, and public-sector cuts targeting social benefits. The specialisation in the energy sector and option for the local population to find a 'safe job' with relatively high salaries in the public sector combined with limited diversification of the regional economy to leave this region yet more vulnerable than the others analysed to exogenous shocks. The crisis increased levels of interest in volunteering and in participating in collective actions in the name of social solidarity (NGOs, citizens' groups, local initiatives, etc.). An increase in regional collaboration and networking are considered critical if regional renewal is to take place. The regional population is characterised by traditional values, with a patriarchal family structure that proved up to the task of absorbing the first wave of consequences arising out of the economic crisis. This shows that a strategy designed to help turbulence be survived can also base itself on broad networks of family and friends. The more social and professional contacts families have, the more resilient is the society and whole system they live within. Policy makers implemented ad hoc and fragmented policies that may have benefited specific types of activity, or may have helped specific types of problems to be overcome, but had only a limited and rather temporary effect upon the resilience of the region. As there was limited experience among regional authorities in the design and implementation of development programs, these authorities needed to be enforced by an influx of skilled professionals and by technical assistance.

The regional economy of Uusimaa (with Helsinki) in Finland is characterized by a dominance of the services sector, as well as strong ITC and logistics sectors. During the crisis, the resistance in production proved weak, while the economy overall displayed strong resistance as regards employment and income. This reflects the nature of the Nordic-type welfare system. However, there were factors that hindered the recovery of Uusimaa's economy, notably insufficient reorientation following the weakening of the Nokia cluster and loss of certain export opportunities. Paradoxically, a strong reliance on the global success of Nokia was considered to contribute to the slower recovery and renewal of the regional 
economy. Also over-reliance on the aforesaid Nordic approach to welfare may hamper reallocation of resources (labour and capital), and thus also reorientation and renewal. This may be not beneficial in the event of future economic shocks. The Uusimaa region nevertheless demonstrated slightly greater resistance to the crisis than the rest of the Finland - a circumstance considered to relate to the dominance of the services sector, and the abundance of public-sector jobs. Contrasting with the Western Macedonia observations, and here crucial, is the size (dominance) of the public sector. Other regional factors contributing to resilience were shown to be diversity of the regional economy, size of the labor market, and good international connectivity. Policymakers can strengthen the resilience of a region by way of a responsible budget policy, constant support for innovation and the promotion of a famously strong education system. It is emphasised that the decline of Nokia and resulting surplus of highly-skilled workforce combined with high-quality intellectual property to represent an important source of renewal.

\section{Conclusions}

Analysis of the resilience of selected European regions indicates that the diversity of economic and social structures is one of the fundamental principles underpinning the building of regions resilient to crises. The experience of the last period of recession in the world has shown that diversification should be understood, not only as a variety of economic activities in the field of high-tech manufacturing and services (including financial), but also in relation to production-related and industrial activity. The evidence provides examples of regions displaying a high level of resistance, like Baden-Württemberg and Pomorskie.

Just as diversification of the economy is a recurrent element to the stabilisation and strengthening of regions, so having a wealth of human and social capital is a factor that can strengthen the potential for resilience markedly. Its role is strategic in the event of a crisis. Qualified human capital of a region allows for rapid restructuring of declining industries during a crisis. The social network integration and cooperation that grow out of social capital make self-help support actions in times of crisis a real possibility. The presence of regionally-embedded companies and entrepreneurs, as well as relationships between employers and employees based on mutual trust allowed most regions to alleviate the social impact of the crisis, and maintain an employment policy tailored to the limited job market. Mitigation of the role of social capital was found to be as important in regions recognised as resilient, such as BadenWürttemberg, as in those affected far more deeply by the crisis, like Puglia or Western Macedonia.

During the last crisis, a policy to strengthen the resilience of a region by taking care of the labour market, wages and forms of employment that are varied, and tailored to individual needs and changing conditions was found to have become a key instrument for strategic action. The experience of that crisis shows that almost all of the regions have seen many different instruments deployed in support of the labour market, with a view to the effects of the recession being reduced. A number of solutions would seem to require implementation in medium- and long-term development strategies that should be used in individual action in a more than just temporary fashion.

As was mentioned, there are many tools and policies that can be deployed in an effort to forge a resilient region. An important role of state, regional and local authorities in the wake of an economic crisis is to stabilise the situation. This can be achieved through own actions, but also by helping to reduce the uncertainties that households and firms face. Other activity in public policy seeks to promote economic recovery by helping firms and households adapt to new circumstances. However, in the last crisis, many policy instruments based around public-sector expenditure were limited on account of the prevailing austerity measures. Nevertheless, policy responses to promote recovery in the states and regions 
analysed in more detail included economic stimulus packages, employment support, the promotion of flexible working, support for training, the promotion of entrepreneurship, competitiveness and innovation and an easing of eligibility rules and facilitated access where credit is concerned.

Attempts to assure greater resilience in the future were also made, including the encouragement of economic diversification, tax and investment incentives, and government reform and institutional change. Significant factors supporting resilience in some regions were leadership and dialogue, as well as support for community responses.

Resilient economies are built many years prior to an economic crisis. Policy decisions should be taken years and even decades in advance of economic hardship, in order that a capacity of a region to respond to the shock might truly be shaped. The results of the ESPON project provide a basis for the claim that four features may prove crucial to the development of a resilient economy, i.e. diversity, skills, innovation and good governance. It is regional authorities and other actors who should be responsible for the shaping of regional resilience over the longer time perspective. Regions ought to engage in the active building of resilience, not merely relying on economic agents. It is crucial that there be tailoring to the specific challenges associated with particular places. In fact,

\section{References}

Boschma R., Martin R., 2007. Editorial: Constructing an evolutionary economic geography. Journal of Economic Geography, vol. 7, no. 5, pp. 537-548.

Briguglio L., Cordina G., Farrugia N., Vella S., 2009. Economic Vulnerability and Resilience: Concepts and Measurements. Oxford Development Studies, vol. 37, no. 3, pp. 229-247.

BrISTOW G., 2010. Resilient regions: Re-'place'ing regional competitiveness. Cambridge Journal these challenges tend to be understood particularly well by sub-national policy actors, with this denoting a necessity for place-based actions to be implemented. Actions that integrate national and sub-national approaches are to be preferred over those that focus only on one or the other, given the way that the experience of regional authorities in many European countries during the past crisis demonstrates the limitations of local-level actions. After all, the ability to mobilise financial instruments and resources is greater at national level, particularly when not all places are experiencing the economic shock to the same extent. Resilience is strengthened where risks can be shared across territories, and indeed resilience can be regarded as a shared responsibility, with the costs of any crisis needing to be incurred by various business sectors and various groups in society (see Bristow et al. 2014).

\section{Acknowledgment}

The research presented in this paper was financed by the ESPON 2013 Programme, within the framework of the "Economic Crisis: Resilience of Regions” (ECR2) project.

\section{Editors' note:}

Unless otherwise stated, the sources of tables and figures are the author's, on the basis of their own research. of Regions, Economy and Society, vol. 3, no. 1, pp. 153-167.

Bristow G., Healy A., 2014a. Building resilient regions: Complex adaptive systems and the role of policy intervention. Raumforschung und Raumordnung, vol. 72, no. 2, pp. 93-102.

Bristow G., Healy A., 2014b. Regional resilience: An agency perspective. Regional Studies, vol. 48, no. 5, pp. 923-935.

Bristow G., Healy A., 2015. Crisis response, choice and resilience: Insights from complexity thinking. 
Cambridge Journal of Regions, Economy and Society, vol. 8, no. 2, pp. 241-256.

Bristow G., Healy A., Norris L., Kafkalas G., KaKderi Ch., Swash A., Carey H., Sagan I., Masik G., Wink R., Kirchner L., Koch F., Speda D., Sensier M., Harding A., Espenberg K., Sepp V., VarBLANE U., 2014. ECR2 economic crisis: Resilience of regions. ESPON Applied Research, Final Report.

BRISTOW G., WeLLS P., 2005. Innovative discourse for sustainable local development: A critical analysis of eco-industrialism. International Journal of Innovation and Sustainable Development, vol. 1, no. 1-2, pp. 168-179.

Christopherson S., Michie J., Tyler P., 2010. Regional resilience: Theoretical and empirical perspectives. Cambridge Journal of Regions, Economy and Society, vol. 3, no. 1, pp. 3-10.

CSO, 2015. Central Statistical Office, www. http:// stat.gov.pl/ [11 July 2016]

DAVIDSON D.J., 2010. The applicability of the concept of resilience to social systems: Some sources of optimism and nagging doubts. Society and Natural Resources, vol. 23, no. 12, pp. 1135-1149.

DavouDI S., 2013. Resilience: A bridging concept or a dead end? Planning Theory and Practice, vol. 13, no. 2, pp. 299-307.

FolKE, C., 2006. Resilience: The emergence of a perspective for socialecological systems analyses. Global Environmental Change, vol. 16, no. 3, pp. 253-267.

FOSTER K.A., 2007. A case study approach to understanding regional resilience. Berkeley: Institute of Urban and Regional Development. University of California [typescript].

Gibbs D., Deutz P., Proctor, A., 2005. Industrial ecology and eco-industrial development: A potential, paradigm for local and regional development? Regional Studies, vol. 39, no. 2, pp. 171-183.

Goldstein B.E., Wessells T.A., Lejano, R., Butler W., 2015. Narrating resilience: Transforming urban systems through collaborative storytelling. Urban Studies, vol. 52, no. 7, pp. 1285-1303.

Grochowski M., Dudek-Mańkowska S., FuhrMAnN M., Zegar T., 2012. Sektor kreatywny w województwach pomorskim i kujawsko-pomorskim - raport z badań. Gdańsk: Agencja Rozwoju Pomorza.
HAYTER R., 2004. Economic geography as dissenting institutionalism: The embeddedness, evolution and differentiation of regions. Geografiska Annaler: Series B. Human Geography, vol. 86, no. 2, pp. 95-115.

Healy A., Bristow G., 2013. Economic crisis and the structural funds. ESPON Applied Research Project ECR2. Economic crisis: Resilience of regions. Luxembourg, p. 1-12, https://www.espon. eu/export/sites/default/Documents/Projects/ AppliedResearch/ECR2/OD-ECR2-article_Economic-Crisis-and-the-Structural-Funds.pdf [8 August 2016].

HoluING C.S., 1996. Engineering resilience versus ecological resilience [in:] P.C. Schulze (ed.), Engineering within ecological constraints, Washington D.C.: National Academy Press, pp. 31-44.

HopKINS R., LIPNAN P., 2008. The Transition Network Ltd: Who we are and what we do. Version 1.0, Devon: Transition Network Ltd, Totnes, [typescript].

JACKSON T., 2009. Prosperity without growth? The transition to a sustainable economy. Report for the Sustainable Development Commission, London: Sustainable Development Commission, [typescript].

KĘBŁOWSKI P., WeLlFE A., 2010. Estimation of the equilibrium exchange rate: The CHEER approach. Journal of International Money and Finance, vol. 29, no. 7, pp. 1385-1397.

Komornicki T., Zaucha J., SZejgiec B., Wiśniewski R., 2015. Export relations of local economy in changing situation - spatial analysis, Prace Geograficzne, 250, Warszawa: Instytut Geografii i Przestrzennego Zagospodarowania PAN.

Mackinnon D., Derickson D., K., 2013. From resilience to resourcefulness: A critique of resilience policy and activism. Progress in Human Geography, vol. 37, no. 2, pp. 253-270.

Marshal's Office of the Pomorskie Voivodeship, 2008. Foreign trade of Pomorskie Region in the years 2000-2006. Gdańsk.

MASIK G., 2014. Economic resilience to crisis. The case study of the Pomorskie region in Poland. Economy \& Business Journal of International Scientific Publications, vol. 8, no. 1, pp. 72-83.

MASIK G., RZYSKI, S., 2014. Resilience of Pomorskie region to economic crisis. Bulletin of $\mathrm{Ge}-$ ography. Socio-economic Series, vol. 25, no. 25, pp. 129-141. 
Mclnroy N., LonglandS S., 2010. Productive local economies: Creating resilient places. Manchester: CLES-Centre for Local Economic Strategies [typescript].

Pendall R., Foster K.A., Cowell M., 2010. Resilience and regions: Building understanding of the metaphor. Cambridge Journal of Regions, Economy and Society, vol. 3, no. 1, pp. 71-84.

Petrakos G., Psycharis Y., 2016. The spatial aspects of economic crisis in Greece. Cambridge Journal of Regions, Economy and Society, vol. 9, no. 1, pp. 137-152.

RaCHWAt T., 2011. Wpływ kryzysu na zmiany produkcji przemysłowej w Polsce [in:] Z. Zioło, T. Rachwał (eds.), Wpływ kryzysu na zachowania przedsiębiorstw oraz przemiany struktur regionalnych, Prace Komisji Geografii Przemysłu Polskiego Towarzystwa Geograficznego, no. 17, pp. 99-113.
SAntos T.F., PARTidario R.M., 2011. SPARK: Strategic planning approach for resilience keeping. European Planning Studies, vol. 19, no. 8, pp. 1517-1536.

Simmie J., Martin R., 2010. The economic resilience of regions: Towards an evolutionary approach. Cambridge Journal of Regions, Economy and Society, vol. 3, no. 1, pp. 27-43.

SKELCHER C., 2005. Jurisdictional integrity, polycentrism, and the design of democratic governance. Governance, vol. 18, no. 1, pp. 89-110.

Statistical Office In Gdańsk, 2012. Report on the socio-economic situation of Pomorskie Region in 2011. Gdańsk.

SzejgieC B., Komornicki T., 2015. Spatial differentiation of Polish export linkages. Geographia Polonica, vol. 88, no. 1, pp. 173-178. 